\title{
Chemical Constituents of Nepalese Propolis (II)
}

\author{
Suraj Prakash Shrestha, Yuji NARUKawa, and Tadahiro TAKedA* \\ Kyoritsu University of Pharmacy; 1-5-30 Shibakoen, Minato-ku, Tokyo 105-8512, Japan. \\ Received January 18, 2007; accepted March 26, 2007; published online April 6, 2007
}

A novel flavanonol (1), three new isoflavones (2-4) and a new flavan-3-ol (5) were isolated along with ten other known flavonoids (6-15) from the methanolic extract of propolis collected from Chitwan, Nepal. Their structures were determined on the basis of spectral analysis.

Key words propolis; dihydroflavonol; isoflavone; flavan-3-ol; stopped-flow LC-CD spectrum

Propolis, a complex resinous material collected by honeybees from buds and exudates of certain plant sources neighboring its hive, is considered to possess broad spectrum of biological activities and has historical utilization in folk medicine. Thus, it is extensively being used in health food, pharmaceutical preparations etc. The chemical consistency of propolis is highly dependent on the flora of the region from where it is collected. ${ }^{1-5)}$

As a part of our ongoing study on propolis of different geographical locations of Nepal, previously we have reported three new and nine known flavonoids from propolis of Chitwan. ${ }^{6}$ In this paper, we will report on further isolation of new compounds from the remaining fractions and sub fractions of the same propolis.

\section{Results and Discussion}

The separation of untouched fraction 2 by column of MCI gel CHP-20P followed by Lobar RP-8 column, normalphase PTLC and ODS HPLC, and continued chromatography of fraction 3 by normal-phase PTLC and ODS HPLC afforded five new compounds $(\mathbf{1}-\mathbf{5})$ together with ten previously reported compounds: Odoratin (6), ${ }^{7)}(+)$-Medicarpin (7), ${ }^{8)}(+)$-Vesticarpan $(8),{ }^{9)}$ Plathymenin $(9),{ }^{10)}(2 S)-7-$ Methoxyflavanone (10), ${ }^{11)}(2 S)$-7-Hydroxyflavanone (11), ${ }^{12}$ $S$-4-Methoxydalbergiquinol (12), ${ }^{13)} \quad(4 S, 6 S)-4-H y d r o x y-3-$ methoxy-6-(1-phenyl-2-propenyl)-2-cyclohexene-1-one $(\mathbf{1 3}),{ }^{14)}$ Cearoin $(\mathbf{1 4})^{15)}$ and $(1 R, 2 S, 4 S, 5 S)-2-$ methoxy-5-
[(1R)-1-phenyl-2-propenyl]-1,4-cyclohexanediol (15). ${ }^{14)}$

Compound 1 was obtained as yellow crystals with molecular formula $\mathrm{C}_{15} \mathrm{H}_{12} \mathrm{O}_{5}$, as established by the molecular ion peak at $m / z: 272.0655[\mathrm{M}]^{+}$in its HR-EI-MS. Its ${ }^{1} \mathrm{H}-\mathrm{NMR}$ spectrum (Table 1) displayed two trans-diaxially related oxygenated methine doublets at $\delta_{\mathrm{H}} 5.04(1 \mathrm{H}, \mathrm{d}, J=11.7 \mathrm{~Hz}, \mathrm{H}-2)$ and $4.48(1 \mathrm{H}, \mathrm{d}, J=11.7 \mathrm{~Hz}, \mathrm{H}-3)$, signals due to a monosubstituted benzene ring at $\delta_{\mathrm{H}} 7.54(2 \mathrm{H}, \mathrm{dd}, J=8.0,1.4 \mathrm{~Hz}$, $\left.\mathrm{H}-2^{\prime}, 6^{\prime}\right), 7.41\left(1 \mathrm{H}, \mathrm{dt}, J=8.0,1.4 \mathrm{~Hz}, \mathrm{H}-3^{\prime}, 5^{\prime}\right)$ and $7.38(1 \mathrm{H}$,

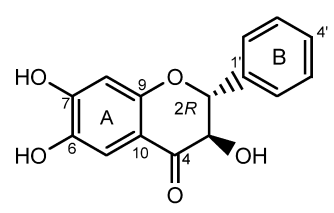

1<smiles>COc1c(O)ccc2c1CC(O)C(c1ccccc1)O2</smiles>

5
Fig. 1. Structures of New Compounds $(\mathbf{1}-\mathbf{5})$

Table $1 .{ }^{1} \mathrm{H}-\mathrm{NMR}$ Data $(\delta, J$ in $\mathrm{Hz})$ of Compounds $\mathbf{1}-\mathbf{5}(500 \mathrm{MHz})$

\begin{tabular}{|c|c|c|c|c|c|}
\hline Proton & $\mathbf{1}^{a)}$ & $\mathbf{2}^{a)}$ & $\mathbf{3}^{b)}$ & $\mathbf{4}^{a)}$ & $\mathbf{5}^{a)}$ \\
\hline 2 & $5.04 \mathrm{~d}(11.7)$ & $8.16 \mathrm{~s}$ & $8.18 \mathrm{~s}$ & $8.12 \mathrm{~s}$ & $4.61 \mathrm{~d}(5.0)$ \\
\hline 3 & $4.48 \mathrm{~d}(11.7)$ & & & & 3.96 ddd $(10.0,5.0,2.5)$ \\
\hline \multirow[t]{2}{*}{4} & & & & & $2.85 \mathrm{dd}(14.5,2.5)$ \\
\hline & & & & & $2.49 \mathrm{dd}(14.5,10.0)$ \\
\hline 5 & $7.19 \mathrm{~s}$ & $7.58 \mathrm{~d}(8.5)$ & $8.27 \mathrm{~s}$ & $7.55 \mathrm{~s}$ & \\
\hline 6 & & 6.96 br d $(8.5)$ & & & \\
\hline 7 & & & & & $6.52 \mathrm{~d}(8.5)$ \\
\hline 8 & $6.39 \mathrm{~s}$ & 6.95 br s & $7.28 \mathrm{~s}$ & $6.92 \mathrm{~s}$ & $6.47 \mathrm{~d}(8.5)$ \\
\hline $2^{\prime}$ & $7.54 \mathrm{dd}(8.0,1.4)$ & 6.95 br s & $7.80 \mathrm{~d}(2.0)$ & 6.97 br s & $7.42 \mathrm{dd}(7.3,1.5)$ \\
\hline $3^{\prime}$ & $7.41 \mathrm{dt}(8.0,1.4)$ & & & & $7.33 \mathrm{dt}(7.3,1.5)$ \\
\hline $4^{\prime}$ & $7.38 \mathrm{tt}(8.0,1.4)$ & & & 6.97 br s & $7.25 \mathrm{tt}(7.3,1.5)$ \\
\hline $5^{\prime}$ & $7.41 \mathrm{dt}(8.0,1.4)$ & & $7.03 \mathrm{~d}(8.4)$ & & $7.33 \mathrm{dt}(7.3,1.5)$ \\
\hline $6^{\prime}$ & $7.54 \mathrm{dd}(8.0,1.4)$ & 7.06 br s & $7.33 \mathrm{dd}(8.4,2.0)$ & 7.05 br s & $7.42 \mathrm{dd}(7.3,1.5)$ \\
\hline $5 \mathrm{OMe}$ & & & & & $3.62 \mathrm{~s}$ \\
\hline $6 \mathrm{OMe}$ & & & & $3.95 \mathrm{~s}$ & \\
\hline $4^{\prime} \mathrm{OMe}$ & & & $3.77 \mathrm{~s}$ & & \\
\hline $5^{\prime} \mathrm{OMe}$ & & $3.87 \mathrm{~s}$ & & $3.88 \mathrm{~s}$ & \\
\hline
\end{tabular}

a) Measured in $\mathrm{CD}_{3} \mathrm{OD}$. b) Measured in $\mathrm{C}_{5} \mathrm{D}_{5} \mathrm{~N}$. 
$\left.\mathrm{tt}, J=8.0,1.4 \mathrm{~Hz}, \mathrm{H}-4^{\prime}\right)$, and two aromatic singlet protons at $\delta_{\mathrm{H}} 7.19(1 \mathrm{H}, \mathrm{s}, \mathrm{H}-5)$ and $\delta_{\mathrm{H}} 6.39(1 \mathrm{H}, \mathrm{s}, \mathrm{H}-8)$. Consistent with the ${ }^{1} \mathrm{H}-\mathrm{NMR}$ spectral analysis, the ${ }^{13} \mathrm{C}$-NMR spectrum of 1 also displayed two oxygenated methine type resonances at $\delta_{\mathrm{C}} 85.9(\mathrm{C}-2)$ and $\delta_{\mathrm{C}} 74.8(\mathrm{C}-3)$, the signals due to two aromatic rings (with one mono-substituted) (Table 2), and a conjugated ketone at $\delta_{\mathrm{C}} 194.4(\mathrm{C}-4)$. Accordingly, this suggested that compound 1 could be a flavanonol with an unsubstituted B ring. ${ }^{16-18)}$ Thus, presence of three hydroxyl groups in 1 could be inferred from the molecular formula $\mathrm{C}_{15} \mathrm{H}_{12} \mathrm{O}_{5}$. Also, by comparing with literature values of similar compounds, the position of hydroxyl group attached to carbons at $\delta_{\mathrm{C}} 138.9$ and $\delta_{\mathrm{C}} 156.1$ in ${ }^{13} \mathrm{C}$-NMR spectrum could be unambiguously assigned to position 6 and 7 , respectively. ${ }^{19)}$ This hypothesized structure was confirmed by HMBC correlations as summarized in Fig. 2a. The stopped-flow LC-CD spectrum of compound $\mathbf{1}$ displayed positive and negative Cotton effects at $338 \mathrm{~nm}$ and $286 \mathrm{~nm}$, respectively, which suggests the absolute stereochemistry of $\mathrm{C}-2$ to be $R .^{20)}$ Thus,

Table 2. ${ }^{13} \mathrm{C}-\mathrm{NMR}$ Data $(125 \mathrm{MHz})$ of Compounds $\mathbf{1}-\mathbf{5}$

\begin{tabular}{lrrrrr}
\hline \hline Position & $\mathbf{1}^{a)}$ & $\mathbf{2}^{a)}$ & $\mathbf{3}^{b)}$ & $\mathbf{4}^{a)}$ & $\mathbf{5}^{a)}$ \\
\hline 2 & 85.9 & 154.6 & 152.5 & 154.6 & 78.4 \\
3 & 74.8 & 125.3 & 124.2 & 126.5 & 77.2 \\
4 & 194.4 & 178.5 & 175.7 & 177.7 & 33.3 \\
5 & 111.7 & 117.4 & 109.5 & 105.5 & 148.2 \\
6 & 138.9 & 115.4 & 146.5 & 148.8 & 139.4 \\
7 & 156.1 & 151.7 & 154.4 & 155.3 & 121.8 \\
8 & 104.2 & 112.7 & 103.7 & 104.0 & 111.8 \\
9 & 158.8 & 148.4 & 152.2 & 154.4 & 146.0 \\
10 & 112.6 & 118.8 & 118.2 & 117.8 & 124.8 \\
$1^{\prime}$ & 138.9 & 126.3 & 126.7 & 125.3 & 143.5 \\
$2^{\prime}$ & 128.9 & 121.7 & 117.9 & 112.7 & 128.3 \\
$3^{\prime}$ & 129.4 & 134.2 & 147.9 & 147.5 & 129.0 \\
$4^{\prime}$ & 129.7 & 147.4 & 148.6 & 121.7 & 129.0 \\
$5^{\prime}$ & 129.4 & 149.2 & 112.4 & 149.2 & 129.0 \\
$6^{\prime}$ & 128.9 & 117.5 & 120.5 & 117.5 & 128.3 \\
5 OMe & & & & & 60.7 \\
6 OMe & & & & 56.7 & \\
$4^{\prime} \mathrm{OMe}$ & & & 56.0 & & \\
$5^{\prime}$ OMe & & 56.5 & & 56.5 & \\
\hline
\end{tabular}

a) Measured in $\mathrm{CD}_{3} \mathrm{OD}$. b) Measured in $\mathrm{C}_{5} \mathrm{D}_{5} \mathrm{~N}$.

a)

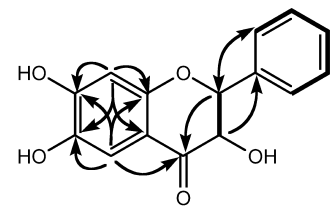

the new compound $\mathbf{1}$ was structurally characterized as $(2 R, 3 R)-3,6,7$-trihydroxyflavanone.

Compound 2 was isolated as colorless crystals and gave a molecular ion peak at $m / z: 301.0695[\mathrm{M}+\mathrm{H}]^{+}$in its HRFAB-MS corresponding to molecular formula $\mathrm{C}_{16} \mathrm{H}_{12} \mathrm{O}_{6}$. The absorption band at $260 \mathrm{~nm}$ in the UV spectrum in combination with a singlet resonance in ${ }^{1} \mathrm{H}-\mathrm{NMR}$ spectrum (Table 1) at $8.16 \mathrm{ppm}$ and corresponding olefinic oxymethine signal in ${ }^{13} \mathrm{C}-\mathrm{NMR}$ spectrum (Table 2) at $154.6 \mathrm{ppm}$ due to $\mathrm{H}-2$ and $\mathrm{C}-2$, respectively, suggested this compound to have an isoflavone skeleton. ${ }^{16,18,21)}$ The substitution pattern of ring A and ring $\mathrm{B}$ was determined by analysis of coupling constants, and ${ }^{1} \mathrm{H}-{ }^{1} \mathrm{H}$ COSY, HMQC and HMBC experiments. A pair of $\mathrm{AB}$ proton doublets at $\delta_{\mathrm{H}} 7.58(1 \mathrm{H}, \mathrm{d}, J=8.5 \mathrm{~Hz})$ and $\delta_{\mathrm{H}}$ $6.96(1 \mathrm{H}$, brd,$J=8.5 \mathrm{~Hz})$ along with a broad singlet at $\delta_{\mathrm{H}}$ 6.95 observed in ${ }^{1} \mathrm{H}-\mathrm{NMR}$ spectrum were assigned to aromatic protons H-5, H-6 and H-8, respectively, while hydroxyl group attached to carbon $\left(\delta_{\mathrm{C}} 151.7\right)$ was placed at position 7 on the basis HMBC cross-peaks observed for $\mathrm{H}-5$ with $\mathrm{C}-4$, C-7 and C-9, and for $\mathrm{H}-8$ with C-6, C-7, C-9 and C-10. Moreover, HMBC cross-peaks observed for the broad singlets at $\delta_{\mathrm{H}} 6.95\left(\mathrm{H}-2^{\prime}\right)$ and $\delta_{\mathrm{H}} 7.06\left(\mathrm{H}-6^{\prime}\right)$ with $\mathrm{C}-3$ and $\mathrm{C}-4^{\prime}$ $\left(\delta_{\mathrm{C}} 147.4\right)$, for $\mathrm{H}-2^{\prime}$ with $\mathrm{C}-3^{\prime}\left(\delta_{\mathrm{C}} 134.2\right)$, and for methoxyl protons and H-6' with $\mathrm{C}-5^{\prime}\left(\delta_{\mathrm{C}} 149.2\right)$ implied the $\mathrm{B}$ ring substitution pattern for 2 to be as shown in Fig. 2b. The position of methoxyl group was further confirmed by the NOESY interaction observed between $\mathrm{H}-6^{\prime}$ and the methoxyl protons. Thus, the structure of $\mathbf{2}$ was determined to be $5^{\prime}$ methoxy-7,3', $4^{\prime}$-trihydroxyisoflavone.

Compound 3 was isolated as colorless crystals, and has molecular formula $\mathrm{C}_{16} \mathrm{H}_{12} \mathrm{O}_{6}$ as determined by the molecular ion peak at $m / z: 301.0695[\mathrm{M}+\mathrm{H}]^{+}$in its HR-FAB-MS. Like in compound 2 , a singlet at $8.18 \mathrm{ppm}(\mathrm{H}-2)$ in its ${ }^{1} \mathrm{H}-\mathrm{NMR}$ spectrum in combination with resonances at $152.5 \mathrm{ppm}(\mathrm{C}-2)$ and $175.7 \mathrm{ppm}(\mathrm{C}-4)$ in ${ }^{13} \mathrm{C}-\mathrm{NMR}$ spectrum concluded this compound to have an isoflavone skeleton. A sharp singlet at $\delta_{\mathrm{H}} 8.27(1 \mathrm{H}, \mathrm{s})$ which showed HMBC correlation with the signal due to the carbonyl carbon (C-4) was assigned $\mathrm{H}-5$, while another singlet at $\delta_{\mathrm{H}} 7.28(1 \mathrm{H}, \mathrm{s})$ was attributed to $\mathrm{H}-8$ and the hydroxyl groups were placed at position 6 and 7 on the basis of HMBC cross-peaks observed for H-5 and H-8

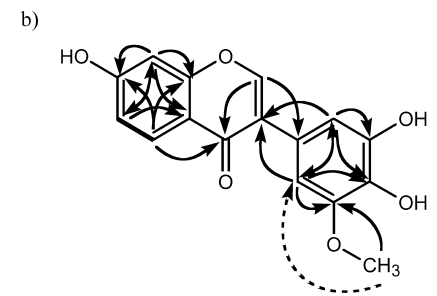

c)

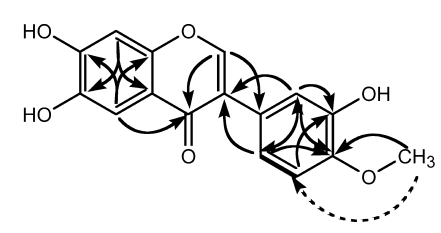

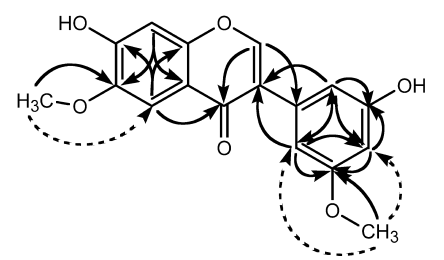

e)

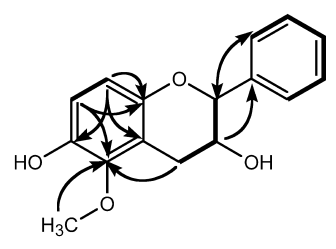

Fig. 2. (a), (b), (c), (d) and (e) Connectivities (Bold Lines) Deduced by the COSY Spectrum and Significant HMBC Correlations (Arrow) Observed for 1, 2, 3, 4 and 5, Respectively. Selected NOESY Correlations (Dashed Arrow) Observed for 2, 3 and 4. 
with C-6 $\left(\delta_{\mathrm{C}} 146.5\right), \mathrm{C}-7\left(\delta_{\mathrm{C}} 154.4\right), \mathrm{C}-9\left(\delta_{\mathrm{C}} 152.2\right)$ and C$10\left(\delta_{\mathrm{C}} 118.2\right)$. The decision concerning the relative position of hydroxyl group at 6 and 7 was made by comparing the ${ }^{13} \mathrm{C}$-NMR data with literature values. ${ }^{19)}$ The signals due to an $\mathrm{ABX}$ spin system at $\delta_{\mathrm{H}} 7.03(1 \mathrm{H}, \mathrm{d}, J=8.4 \mathrm{~Hz}), \delta_{\mathrm{H}} 7.33(1 \mathrm{H}$, $\mathrm{dd}, J=8.4,2.0 \mathrm{~Hz})$ and $\delta_{\mathrm{H}} 7.80(1 \mathrm{H}, \mathrm{d}, J=2.0 \mathrm{~Hz})$ observed in ${ }^{1} \mathrm{H}-\mathrm{NMR}$ spectrum were assigned to aromatic protons $\mathrm{H}-$ $5^{\prime}, \mathrm{H}-6^{\prime}$ and $\mathrm{H}-2^{\prime}$, respectively, on the basis of HMBC correlations from $\mathrm{H}-2^{\prime}, \mathrm{H}-6^{\prime}$ to $\mathrm{C}-3$. The $\mathrm{HMBC}$ correlations from $\mathrm{H}-2^{\prime}, \mathrm{H}-6^{\prime}$ and methoxyl protons to $\mathrm{C}-4^{\prime}\left(\delta_{\mathrm{C}} 148.6\right)$, from $\mathrm{H}-2^{\prime}$ and $\mathrm{H}-5^{\prime}$ to $\mathrm{C}-3^{\prime}\left(\delta_{\mathrm{C}} 147.9\right)$ together with the NOESY correlation between $\mathrm{H}-5^{\prime}$ and the methoxyl protons confirmed the position of methoxyl group at $4^{\prime}$ and hydroxyl group at $3^{\prime}$.

The HR-FAB-MS of compound 4 displayed molecular ion at $m / z 315.0890[\mathrm{M}+\mathrm{H}]^{+}$, in agreement with the molecular formula $\mathrm{C}_{17} \mathrm{H}_{14} \mathrm{O}_{6}$. Its ${ }^{1} \mathrm{H}$-NMR spectrum also showed the characteristic singlet at $8.12 \mathrm{ppm}$ for isoflavone along with five singlets in aromatic region and two signals for methoxyl group at $\delta_{\mathrm{H}} 3.95$ and $\delta_{\mathrm{H}} 3.88$, while its ${ }^{13} \mathrm{C}$-NMR spectrum resembled to that of $\mathbf{3}$ except in having one additional signal for methoxyl group at $\delta_{\mathrm{C}} 56.7\left(\mathrm{OCH}_{3}-6\right)$, downfield shift of signal due to $5^{\prime}$ and upfield shift of signal due to $4^{\prime}$, indicating the presence of hydroxyl or methoxyl function at position $6,7,3^{\prime}$ and $5^{\prime}$ in 4 instead of $6,7,3^{\prime}$ and $4^{\prime}$ in 3 . Observation of $\mathrm{HMBC}$ correlation from $\mathrm{OCH}_{3}-6$ to $\mathrm{C}-6$, from $\mathrm{OCH}_{3}-5^{\prime}$ to $\mathrm{C}-5^{\prime}$ implied the hydroxyl group to be linked to $\mathrm{C}-7$ and $\mathrm{C}$ $3^{\prime}$, and methoxyl group to be linked to $\mathrm{C}-6$ and $\mathrm{C}-5^{\prime}$, with other HMBC correlations in $\mathbf{4}$ being the same as those of $\mathbf{3}$. In addition, the NOESY cross-peak between $\mathrm{H}-5$ and $\mathrm{OCH}_{3}-$ 6 , and $\mathrm{H}^{-} 6^{\prime}$ and $\mathrm{OCH}_{3}-5^{\prime}$ also confirmed positions of methoxyl groups at position 6 and $5^{\prime}$.

Compound $\mathbf{5}$ was isolated as yellow solid, and has molecular formula $\mathrm{C}_{16} \mathrm{H}_{16} \mathrm{O}_{4}$ as determined by the molecular ion peak at $m / z: 273.1125[\mathrm{M}+\mathrm{H}]^{+}$in its HR-FAB-MS. Its ${ }^{1} \mathrm{H}-$ NMR spectrum showed four signals due to two methine protons at $4.61(1 \mathrm{H}, \mathrm{d}, J=5.0 \mathrm{~Hz}), 3.96(1 \mathrm{H}$, ddd, $J=10.0,5.0$, $2.5 \mathrm{~Hz})$ and methylene protons at $2.85(1 \mathrm{H}, \mathrm{dd}, J=14.5$, $2.5 \mathrm{~Hz}), 2.49(1 \mathrm{H}, \mathrm{dd}, J=14.5,10.0 \mathrm{~Hz})$ suggesting this compound could be a flavan-3-ol. ${ }^{22}$ This suggestion was further supported by the signals observed in its ${ }^{13} \mathrm{C}$-NMR spectrum at $\delta_{\mathrm{C}} 78.4,77.2$ and 33.3 for C-2, C-3 and C-4, respectively. ${ }^{18,22)}$ Moreover, the signals at $\delta_{\mathrm{H}} 7.42(2 \mathrm{H}$, dd, $J=7.3$, $\left.1.5 \mathrm{~Hz}, \mathrm{H}-2^{\prime}, 6^{\prime}\right), 7.33\left(2 \mathrm{H}, \mathrm{dt}, J=7.3,1.5 \mathrm{~Hz}, \mathrm{H}-3^{\prime}, 5^{\prime}\right)$ and $7.25\left(1 \mathrm{H}, \mathrm{tt}, J=7.3,1.5 \mathrm{~Hz}, \mathrm{H}-4^{\prime}\right)$ suggested ring B to be unsubstituted. The two ortho-coupled doublets at $\delta_{\mathrm{H}} 6.52(1 \mathrm{H}$, $\mathrm{d}, J=8.5 \mathrm{~Hz})$ and $6.47(1 \mathrm{H}, \mathrm{d}, J=8.5 \mathrm{~Hz})$ were assigned to aromatic protons $\mathrm{H}-7$ and $\mathrm{H}-8$, respectively, on the basis of HMBC cross-peaks observed for H-8 with C-9 and C- 10 . The HMBC cross-peaks observed for a singlet due to methoxyl group at $\delta_{\mathrm{H}} 3.62$ and protons at position 4 with C-5 concluded the position of methoxyl group at position 5. Full assignment of the ${ }^{1} \mathrm{H}$ - and ${ }^{13} \mathrm{C}$-NMR chemical shifts were established by the analysis of $\mathrm{H}-\mathrm{H}$ COSY, HMQC and HMBC spectral data as shown in Fig. 2e furnishing compound $\mathbf{5}$ as 3,6-diol-5-methoxyflavan.

\section{Experimental}

General Optical rotations were measured on a JASCO DIP-1000 polarimeter. ${ }^{1} \mathrm{H}-$, ${ }^{13} \mathrm{C}-\mathrm{NMR}$ spectra were recorded on a JEOL A-500 FT-NMR spectrometer, and the chemical shifts were expressed in the $\delta(\mathrm{ppm})$ scale with the TMS as an internal standard. FAB-MS, HR-FAB-MS, EI-MS and
HR-EI-MS were recorded on a JEOL JMS-700 spectrometer. Analytical and preparative TLC were performed on precoated silica gel $60 \mathrm{~F}_{254}$ or RP-18 $\mathrm{F}_{254} \mathrm{~S}$ plates (Merck, 0.25 or $0.50 \mathrm{~mm}$ thickness), and detection was carried out by spraying EtOH- $\mathrm{H}_{2} \mathrm{SO}_{4}$ reagent followed by heating. Column chromatography was carried out on a silica gel (Silica gel 60, Merck), Lobar LiChroprep RP-18 (Merck), Diaion HP-20 (Mitsubishi Chemical Corporation) and MCI gel CHP-20P (Mitsubishi Chemical Corporation). HPLC-CD spectra were measured in stopped-flow mode using Capcell Pak $\mathrm{C}_{18}$ column ( $5 \mu \mathrm{m}, 4.6 \mathrm{~mm}$ i.d. $\times 250 \mathrm{~mm}$, Shiseido Fine Chemicals) at room temperature, eluted with $\mathrm{MeOH}-\mathrm{H}_{2} \mathrm{O}(2: 3)$ at flow rate of $0.5 \mathrm{ml} \mathrm{min}^{-1}$ on a Jasco CD-2095 $5_{\text {Plus }}$ Chiral detector equipped with two Shimadzu LC-10ADvP pumps, CTO-10A $v P$ column oven and SCL-10A $V P$ system controller.

Biological Material Propolis was collected in Chitwan, Nepal, in 2005. A Voucher specimen has been deposited at the Division of Natural medicines, Kyoritsu University of Pharmacy.

Extraction and Isolation Propolis $(500 \mathrm{~g})$ collected from Chitwan (Nepal), was successively extracted with refluxing $\mathrm{MeOH}$ and water to give methanol $(303 \mathrm{~g})$ and water $(35.3 \mathrm{~g})$ extracts, respectively. Part of the $\mathrm{MeOH}$ extract $(70.7 \mathrm{~g})$ was passed through Diaion HP-20 and eluted successively with $\mathrm{H}_{2} \mathrm{O}, 50 \% \mathrm{MeOH}, \mathrm{MeOH}$ and $\mathrm{CHCl}_{3}$ to get water eluate $(0.61 \mathrm{~g}), 50 \%$ $\mathrm{MeOH}$ eluate $(19.0 \mathrm{~g}), \mathrm{MeOH}$ eluate $(43.2 \mathrm{~g})$ and $\mathrm{CHCl}_{3}$ eluate $(5.40 \mathrm{~g})$, respectively. The $50 \% \mathrm{MeOH}$ eluate was further subjected to a column of MCI gel CHP-20P eluted with $\mathrm{CH}_{3} \mathrm{CN}-\mathrm{MeOH}-\mathrm{H}_{2} \mathrm{O}(1: 1: 4 \rightarrow 1: 1: 0)$ to afford five subfractions [fr. 1: $\mathrm{CH}_{3} \mathrm{CN}-\mathrm{MeOH}-\mathrm{H}_{2} \mathrm{O}(1: 1: 4)$ eluate, $1.15 \mathrm{~g}$; fr. 2: $\mathrm{CH}_{3} \mathrm{CN}-\mathrm{MeOH}-\mathrm{H}_{2} \mathrm{O}(1: 1: 3)$ eluate, $3.32 \mathrm{~g}$; fr. $3: \mathrm{CH}_{3} \mathrm{CN}-\mathrm{MeOH}-\mathrm{H}_{2} \mathrm{O}$ $(1: 1: 2)$ eluate, $5.43 \mathrm{~g}$; fr. $4 \mathrm{CH}_{3} \mathrm{CN}-\mathrm{MeOH}-\mathrm{H}_{2} \mathrm{O}(1: 1: 1)$ eluate, $6.09 \mathrm{~g}$; fr. 5: $\mathrm{CH}_{3} \mathrm{CN}-\mathrm{MeOH}-\mathrm{H}_{2} \mathrm{O}(1: 1: 0)$ eluate, $\left.1.33 \mathrm{~g}\right]$.

Fraction $2(3.32 \mathrm{~g})$ was fractionated over a MCI gel CHP-20P column eluted with $\mathrm{CH}_{3} \mathrm{CN}-\mathrm{H}_{2} \mathrm{O}(1: 4 \rightarrow 1: 0)$ to get six fractions (fr. $2 \mathrm{a}-1,0.02 \mathrm{~g}$; fr. 2a-2, 1.02 g; fr. 2a-3, 1.09 g; fr. 2a-4, 0.62 g; fr. 2a-5, 0.47 g; fr. 2a-6, 0.10 g). Subfraction 2a-1 to 2a-4 were chromatographed on Lobar RP-8 column with $\mathrm{H}_{2} \mathrm{O}-\mathrm{MeOH}\left(40 \% \rightarrow 0 \% \mathrm{H}_{2} \mathrm{O}\right)$, followed by normal-phase preparative TLC with $\mathrm{CH}_{3} \mathrm{CN}-\mathrm{C}_{6} \mathrm{H}_{6}(1: 8)$ and ODS gel preparative HPLC $\left(\mathrm{CH}_{3} \mathrm{CN}: \mathrm{H}_{2} \mathrm{O}\right.$, $1: 3-4: 1)$ to get $4(21.5 \mathrm{mg}), \mathbf{6}(9.70 \mathrm{mg}), 7(208.4 \mathrm{mg}), 8(17.6 \mathrm{mg}), \mathbf{9}$ $(40.1 \mathrm{mg}), \mathbf{1 0}(7.41 \mathrm{mg}), \mathbf{1 1}(27.6 \mathrm{mg})$ and $\mathbf{1 5}(19.3 \mathrm{mg})$.

Fraction $3(5.43 \mathrm{~g})$ was rechromatographed on MCI gel CHP-20P column with $\mathrm{CH}_{3} \mathrm{CN}-\mathrm{MeOH}-\mathrm{H}_{2} \mathrm{O}(1: 1: 4 \rightarrow 1: 1: 0)$ to afford six subfractions (fr. 2-1, $0.06 \mathrm{~g}$; fr. 2-2, $1.23 \mathrm{~g}$; fr. 2-3, $1.01 \mathrm{~g}$; fr. $2-4,1.60 \mathrm{~g}$; fr. 2-5, $0.74 \mathrm{~g}$; fr. 2$6,0.12 \mathrm{~g}$ ). Subfractions 2-2 to 2-6 were further chromatographed on Lobar RP-18 column eluted with $\mathrm{H}_{2} \mathrm{O}-\mathrm{MeOH}\left(40 \% \rightarrow 0 \% \mathrm{H}_{2} \mathrm{O}\right)$, followed by normal-phase preparative TLC with $\mathrm{CH}_{3} \mathrm{CN}-\mathrm{C}_{6} \mathrm{H}_{6}(1: 5)$ and ODS gel preparative HPLC $\left(\mathrm{CH}_{3} \mathrm{CN}: \mathrm{MeOH}: \mathrm{H}_{2} \mathrm{O}, 1: 1: 3-1: 1: 0\right)$, and recrystallization gave $\mathbf{1}(8.3 \mathrm{mg}), \mathbf{2}(33.6 \mathrm{mg}), \mathbf{3}(29.1 \mathrm{mg}), \mathbf{5}(2.45 \mathrm{mg}), \mathbf{1 2}(22.5 \mathrm{mg}), \mathbf{1 3}$ $(52.2 \mathrm{mg})$ and $\mathbf{1 4}(108.1 \mathrm{mg})$.

Compound 1: Yellow crystals; $[\alpha]_{\mathrm{D}}^{26}+28.2^{\circ}\left(c=0.03, \mathrm{CHCl}_{3}\right)$; HR-EI-MS $m / z: 272.0655$ [Calcd for $\mathrm{C}_{15} \mathrm{H}_{12} \mathrm{O}_{5}, 272.0685$ ]; $\mathrm{CD}\left(40 \% \mathrm{MeOH}-\mathrm{H}_{2} \mathrm{O}\right)$ $[\theta]_{338}+3380 ;[\theta]_{286}-15,990 ;{ }^{1} \mathrm{H}$ - and ${ }^{13} \mathrm{C}-\mathrm{NMR}$ data, see Tables 1 and 2.

Compound 2: Colorless crystals; HR-FAB-MS m/z: 301.0695 (Calcd for $\mathrm{C}_{16} \mathrm{H}_{13} \mathrm{O}_{6}[\mathrm{M}+\mathrm{H}]^{+}$, 301.0712); UV (MeOH) $\lambda_{\max } \mathrm{nm}: 260.2,297 ;{ }^{1} \mathrm{H}-$ and ${ }^{13} \mathrm{C}$-NMR, see Tables 1 and 2 .

Compound 3: Colorless crystals; HR-FAB-MS m/z: 301.0695 (Calcd for $\left.\left.\mathrm{C}_{16} \mathrm{H}_{13} \mathrm{O}_{6}[\mathrm{M}+\mathrm{H}]\right]^{+}, 301.0712\right) ;{ }^{1} \mathrm{H}-$ and ${ }^{13} \mathrm{C}-\mathrm{NMR}$, see Tables 1 and 2.

Compound 4: White solid; HR-FAB-MS m/z: 315.0890 (Calcd for $\left.\left.\mathrm{C}_{17} \mathrm{H}_{15} \mathrm{O}_{6}[\mathrm{M}+\mathrm{H}]\right]^{+}, 315.0869\right) ;{ }^{1} \mathrm{H}$ - and ${ }^{13} \mathrm{C}-\mathrm{NMR}$, see Tables 1 and 2.

Compound 5: Yellow solid; $[\alpha]_{\mathrm{D}}^{26}+8.23^{\circ}\left(c=0.01, \mathrm{CHCl}_{3}\right)$; HR-FAB-MS $m / z: 273.1125$ (Calcd for $\left.\mathrm{C}_{17} \mathrm{H}_{15} \mathrm{O}_{5}[\mathrm{M}+\mathrm{H}]^{+}, 273.1127\right) ;{ }^{1} \mathrm{H}-$ and ${ }^{13} \mathrm{C}-\mathrm{NMR}$ data, see Tables 1 and 2.

Acknowledgement The authors are grateful to Ms. J. Hada for providing NMR and MS data.

\section{References}

1) Ghisalberti E. L., Bee World, 60, 59-84 (1979).

2) Burdock G. A., Food Chem. Toxicol., 36, 347-363 (1998).

3) Marcucci M. C., Apidologie, 26, 83-99 (1995).

4) Bankova S. B., De Castro S. L., Marcucci M. C., Apidologie, 31, $3-$ 15 (2000).

5) Banskota A. H., Tezuka Y., Kadota S., Phytother. Res., 15, 561—571 (2001).

6) Shrestha S. P., Narukawa Y., Takeda T., J. Nat. Med., 61, 73-76 (2007).

7) Januario A. H., Lourenco M. V., Domezio L. A., Pietro R. C. L. R., Castilho M. S., Tomazela D. M., Fernandes da Silva M., Vieira P. C., Fernandes J. B., Franca S., Chem. Pharm. Bull., 53, 740-742 (2005). 
8) Belofsky G., Percivill D., Lewis K., Tegos G. P., Ekart J., J. Nat. Prod., 67, 481-484 (2004).

9) Kurosawa K., Ollis D. W., Redman B. T., Sutherland I. O., Gottlieb O. R., Phytochemistry, 17, 1413-1415 (1978).

10) King F. E., King T. J., Neill K. G., J. Chem. Soc., 1055-1059 (1953).

11) Bohlmann F., Jakupovic J., Phytochemistry, 18, 1189-1194 (1979).

12) Tanrisever N., Fronczek F. R., Fischer N. H., Williamson G. B., Phytochemistry, 26, 175-179 (1987).

13) Seshadri T. R., Phytochemistry, 11, 881-898 (1972).

14) Awale S., Shrestha S. P., Tezuka Y., Ueda J., Matsushige K., Kadota S., J. Nat. Prod., 68, 858-864 (2005).

15) Muangnoicharoen N., Frahm A. W., Phytochemistry, 21, 761-772 (1982).
16) Harborne J. B., Mabry T. J., Mabry H., "The Flavonoids," Chapman Hall, London, 1975, p. 97.

17) Su B., Park E. J., Vigo J. S., Grahm J. G., Cabieses F., Fong H. H. S., Pezzuto J. M., Kinghorn A. D., Phytochemistry, 63, 335-341 (2001).

18) Agrawal P. K., "Carbon-13 NMR of Flavonoids," Elsevier, Amsterdam, 1989, pp. 95-235.

19) Iinuma M., Matsuura S., Kusuda K., Chem. Pharm. Bull., 28, 708716 (1980).

20) Gaffield W., Tetrahedron, 26, 4093-4108 (1970).

21) Mabry T. J., Markham K. R., Thomas M. B., "The Systemic Identification of Flavonoids," Springer-Verlag, Berlin, 1975, p. 97.

22) Balde A. M., Pieters L. A., Gergely A., Kolodziej H., Claeys M., Vlietinc A. J., Phytochemistry, 30, 337-342 (1991). 